\title{
RESEARCH ARTICLE \\ Breed and gender-related differences in some hematological parameters of 3-year-old horses in flat racing in Turkey
}

\author{
Berjan DEMİRTAȘ ${ }^{1 *}$ \\ ${ }^{1}$ Istanbul University, Vocational School of Veterinary Medicine, Equine and Training Programme, TR-34320 Avcilar, Istanbul, Turkey \\ Received: 27.12.2017, Accepted: 13.02.2018 \\ *berjan@istanbul.edu.tr

\section{Türkiye'de düz yarışlarda koșan 3 yaşlı atların hematolojik değerlerine ırk ve cinsiyetin etkisi}

\author{
Eurasian J Vet Sci, 2018, 34, 1, 7-12
}

DOI:10.15312/EurasianJVetSci.2018.173

Öz

Amaç: Atların hematolojik değerleri ırk, cinsiyet, yaş ve yetiştiği coğrafyaya göre farklılık gösterebilmektedir. Bu çalışmanın amacı Türkiye'de düz yarışlarda koşan 3 yaşlı atların hematolojik değerlerinde ırk ve cinsiyete bağlı farklılık olup olmadığını araștırmaktır. Ayrıca, Türkiye'de yarışan 3 yaşlı yarış atlarının normal hematolojik değerleri için bir referans oluşturabilmektir.

Gereç ve Yöntem: Bu amaçla 2017 yarış sezonunda İstanbul Veliefendi hipodromunda koşan 3 yaşlı sağlıklı 40 adet Arap (n: 20 aygır, n: 20 kısrak) ve 40 adet İngiliz (n: 20 aygır, n: 20 kısrak) atlarının istirahat halindeki mevcut hemogram değerleri analiz edilmiştir. Hemogram analizine eritrosit sayısı, hemoglobin ve hematokrit değerleri, ortalama eritrosit hacmi, ortalama eritrosit hemoglobin miktarl, ortalama eritrosit hemoglobin konsantrasyonu, eritrosit dağılım genişliği, toplam lökosit sayısı, nötrofil, lenfosit, monosit, eozinofil, bazofil ve trombositsayıları dahil edilmiştir. Veriler iki yönlü varyans analiz metodu kullanılarak Windows SPSS 13 paket programında analiz edilmiştir. Kullanılan istatiksel modelde ırk, cinsiyet ve urk $\mathrm{x}$ cinsiyet etkileşimlerine ana etkenler olarak yer verilmiștir.

Bulgular: Araştırma sonucunda ırkın hematolojik değerler üzerine etkisi olduğu, düz yarışlarda koşan 3 yaşlı İngiliz atlarının eritrosit sayısı $(\mathrm{P}<0.001)$, hemoglobin $(\mathrm{P}<0.001)$ ve hematokrit $(\mathrm{P}<0.001)$ değerlerinin Arap atlarına göre istatiksel açıdan önemli ölçüde yüksek olduğu gözlemlenmiştir. Cinsiyet ve ırk x cinsiyet etkileşiminin herhangi bir parametreye istatiksel açıdan etkisi olmadığı görülmüştür $(\mathrm{P}>0.05)$.

Öneri: Türkiye'de yarışan 3 yaşlı atların hematolojik değerlerinde ırka bağlı farklılıkların olduğu fakat cinsiyete bağlı herhangi bir farklılığın olmadığı saptanmıştır. Diğer ülkelerin Arap ve İngiliz atlarıyla kıyaslandığında Türkiye'de yarışan atların bazı hematolojik değerlerinde farklılık olabileceği görülmüștür. Araştırmacıların kendi ülkelerine özgü referans değerleri oluşturmaları önerilmektedir.

Anahtar kelimeler: Arap, İngiliz, at, düz yarıș, hematoloji
Abstract

Aim: Breed, gender, age and geographical locations affect the hematological values of horses. The aim of this study is to evaluate the breed and gender related differences in hematological parameters of 3 year-old horses running in flat racing in Turkey. A second aim is to establish a preliminary study for the normal ranges of hematological values in 3-year-old horses racing in Turkey.

Materials and Methods: The hemogram data were collected from apparently healthy horses consisting of 40 Arabian (n:20 stallions; n:20 mares) and 40 Thoroughbred (n:20 stallions; n: 20 mares) 3-year-old horses who raced at Istanbul Veliefendi Racetrack in Turkey in 2017. Hemogram parameters were blood counts of red blood cell, hemoglobin, hematocrit, mean corpuscular volume, mean corpuscular hemoglobin, mean corpuscular hemoglobin concentration, red cell dispersion width, white blood cells, neutrophil, lymphocyte, monocyte, eosinophil, basophil and platelet. Data were analyzed by two-way analysis of variance method in SPSS for Windows version 13.0. The statistical model included breed, gender and breed $\mathrm{x}$ gender interactions as main effects.

Results: Red blood cells $(\mathrm{P}<0.001)$, hemoglobin $(\mathrm{P}<0.001)$ and hematocrit $(\mathrm{P}<0.001)$ were found significantly higher in Thoroughbred than Arabian horses. Gender and breed x gender interaction did not have any significant effect on any parameters $(\mathrm{P}>0.05)$.

Conclusion: Breed differences but not gender-related differences were observed in 3-year-old race horses. It seems there are some differences in some hematological parameters of both Arabians and Thoroughbred compared to their counterparts in other countries. It is advisable for researchers to determine their own reference ranges for breeds in their country.

Keywords: Arabian, Thoroughbred, horse, flat racing, hematology 


\section{Introduction}

Flat racing is the most common type of horse racing in the world. Horses run on a racetrack without any obstacles over certain distances in flat races (Hill et al 2010). Countries have variations in their racing rules such as breeds, age, and distance. Thoroughbreds are mainly used in flat racing but Arabian horses are also included in flat racing in more than 30 countries in the world such as Russian Federation, France, Germany, United Arab Emirates, Qatar, United Kingdom, Turkey and many more (Khasanovich and Vladimirovna 2016).

Thoroughbreds start their racing career at the age of 2 whereas Arabians usually at the age of 3 (Khasanovich and Vladimirovna 2016). In Turkey, flat races are held by Turkish Jockey Club (TJK) and both Arabian and Thoroughbred horses are included in flat racing but run separately. Both breeds are bred in stud farms or private farms (Ekiz and Kocak 2005). Racehorses in Turkey are accepted to be born in 1st of January regardless of their actual birth month in Turkey as well as in other northern hemisphere countries (Gramm and Marksteiner 2010).

At the beginning of January, Arabians and Thoroughbreds turning 3 and 2 years old, respectively are brought to racetrack. Thereafter, they are trained on the racetrack for approximately 4 months and start to race usually in April of the racing year.

Hematological parameters are very important indicators for diagnosing and assessing the recovery period of clinical diseases as well as the fitness level of horses (Cebulj-Kadunc et al 2002; Güzelbekteş et al 2006; Altınsaat 2008; Padalino et al 2014). Although the normal range of hematological values for the equine species falls into a broad range, the individual horse has narrow normal range because of physiological variations (Cebulj-Kadunc et al 2002; Meliani et al 2014; McGowan and Hodgson 2014) These variations include mainly the breed, age, gender, and training status of the horses (Cebulj-Kadunc et al 2002; Padalino et al 2014).

It is well accepted that for comparisons between individuals and with reference data, it is necessary to consider these variations in order to increase diagnostic precision or performance capacity of the horses (Meliani et al 2014; Khasanovich and Vladimirovna 2016). Padolino et al (2014) have reported that geographical locations should be taken into account when assessing hematological reference values of different breeds. Hematological values for specific breeds are available (Reed et al 2009) but most are elicited from articles mainly in America, Australia, and Great Britain (Morris 1989). Inspite of hematological values of horses have been studied in different breeds, ages, and genders, there is lack of knowledge about those of Arabian and Thoroughbred horses actively racing in Turkey. Therefore, the aim of this study was to determine the effect of breed and gender on some hematological parameters of apparently healthy 3-yearold horses racing on the same race track in Istanbul, Turkey. A second aim is to establish a preliminary study for the normal ranges of hematological values in 3-year-old horses actively racing in Turkey.

\section{Materials and Methods}

This study was carried out in 80 3-year-old horses deemed to be healthy consisting of 40 Arabian (n: 20 stallions; n: 20 mares) and 40 Thoroughbred (n: 20 stallions; n: 20 mares) horses who raced at Istanbul Veliefendi Racetrack in Turkey in 2017. The study was carried out in accordance with the agreement protocol settled by Turkish Jockey Club.

All horses were stalled in a single box without much use of pastures and trained on the Veliefendi Racecourse. All horses were fed with $60 \%$ concentrate and $40 \%$ forage diet. Forage diet for both breeds were hay. The concentrate diet of Arabians mainly consisted of crashed barley while that of Thoroughbreds was mainly based on crushed oat (90\%) and commercial food (10 $\%)$. Arabians were in their first year of their racing career but Thoroughbreds were in their second. Both breeds were under intense training and raced approximately 2-3 times monthly. It was retrospective study and hemogram analyses were collected randomly for those apparently healthy horses that were brought to Equine Hospital in Veliefendi Racecourse in 2017 for general check-up. Blood samples were collected by jugular venipuncture to ethylenediaminetetraacetic acid vacutainer tubes by veterinarians and hemogram analyses were carried out using Abott Cell-Dyn 3500 Hematology analyzer (Abbott Diagnostics, Santa Clara, CA) in the laboratory of equine hospital.

Hemogram analyses included blood counts of red blood cells (RBC), hemoglobin (HGB), hematocrit (HCT), mean corpuscular volume (MCV), mean corpuscular hemoglobin (MCH), mean corpuscular hemoglobin concentration (MCHC), red cell dispersion width (RDW), total white blood cells (WBC), neutrophils (NEU), lymphocytes (LYM), monocytes (MONO), eosinophils (EOS), basophils (BASO), and platelets (PLT).

The effect of breed, gender, and breed $\mathrm{x}$ gender interactions on these hematological parameters was analyzed and normal ranges of hematological values in these 3 -year-old horses were established.

\section{Statistical analyses}

The hematological parameters had a normal distribution which was assessed by Shapiro-Wilk normality test. Thereafter, they were analyzed by two-way analysis of variance (ANOVA) method in SPSS for Windows version 13.0. The statistical model included breed, gender, and breed $\mathrm{x}$ gender interaction as main effects. P-value $<0.05$ was accepted as statistically significance criterion. Normal range values for each parameter were accepted between lower and upper bounds at $95 \%$ confidence intervals. 
Table 1. Comparisons of erythrocyte parameters between breeds and genders in 3-year-old Arabian and Thoroughbred horses racing in Turkey

\begin{tabular}{|c|c|c|c|c|c|c|c|c|}
\hline & $\mathrm{n}$ & $\begin{array}{c}\mathrm{RBC} \\
(\mathrm{x} 106 / \mu \mathrm{L})\end{array}$ & $\begin{array}{l}\text { HGB } \\
(\mathrm{g} / \mathrm{dl})\end{array}$ & $\begin{array}{l}\text { HCT } \\
(\%)\end{array}$ & $\begin{array}{l}\mathrm{MCV} \\
(\mathrm{fL})\end{array}$ & $\begin{array}{r}\mathrm{MCH} \\
(\mathrm{pg})\end{array}$ & $\begin{array}{l}\text { MCHC } \\
(\mathrm{g} / \mathrm{dL})\end{array}$ & $\begin{array}{l}\text { RDW } \\
(\%)\end{array}$ \\
\hline \multicolumn{9}{|l|}{ Breed } \\
\hline Arabian & 40 & $9.4 \pm 0.2$ & $14.0 \pm 0.2$ & $42.0 \pm 0.5$ & $44.4 \pm 0.4$ & $15.3 \pm 0.1$ & $34.4 \pm 0.1$ & $26.3 \pm 0.3$ \\
\hline Thoroughbred & 40 & $10.6 \pm 0.2$ & $16.0 \pm 0.2$ & $47.0 \pm 0.5$ & $44.0 \pm 0.4$ & $15.2 \pm 0.1$ & $34.5 \pm 0.1$ & $26.7 \pm 0.3$ \\
\hline \multicolumn{9}{|l|}{ Gender } \\
\hline Stallion & 40 & $10.1 \pm 0.2$ & $15.0 \pm 0.2$ & $44.0 \pm 0.5$ & $44.3 \pm 0.4$ & $15.2 \pm 0.1$ & $34.4 \pm 0.1$ & $26.4 \pm 0.3$ \\
\hline Mare & 40 & $10.0 \pm 0.2$ & $15.0 \pm 0.2$ & $44.0 \pm 0.5$ & $44.0 \pm 0.4$ & $15.3 \pm 0.1$ & $34.6 \pm 0.1$ & $26.6 \pm 0.3$ \\
\hline \multicolumn{9}{|l|}{ Breed x Gender } \\
\hline Arabian - Stallion & 20 & $9.4 \pm 0.2$ & $14.3 \pm 0.3$ & $42.0 \pm 0.7$ & $45.0 \pm 0.6$ & $15.4 \pm 0.2$ & $34.3 \pm 0.2$ & $25.9 \pm 0.4$ \\
\hline Arabian - Mare & 20 & $9.4 \pm 0.2$ & $14.3 \pm 0.3$ & $41.0 \pm 0.7$ & $43.8 \pm 0.6$ & $15.2 \pm 0.2$ & $34.6 \pm 0.2$ & $26.6 \pm 0.4$ \\
\hline Thoroughbred-Stallion & 20 & $10.8 \pm 0.2$ & $16.2 \pm 0.3$ & $47.0 \pm 0.7$ & $43.6 \pm 0.6$ & $15.0 \pm 0.2$ & $34.5 \pm 0.2$ & $26.8 \pm 0.4$ \\
\hline Thoroughbred -Mare & 20 & $10.5 \pm 0.2$ & $16.1 \pm 0.3$ & $47.0 \pm 0.7$ & $44.5 \pm 0.6$ & $15.4 \pm 0.2$ & $34.5 \pm 0.2$ & $26.5 \pm 0.4$ \\
\hline SEM & & 0.1 & 0.1 & 0.4 & 0.3 & 0.1 & 0.08 & 0.2 \\
\hline \multicolumn{9}{|l|}{ P-value } \\
\hline Breed & & $<0.001$ & $<0.001$ & $<0.001$ & 0.539 & 0.590 & 0.753 & 0.292 \\
\hline Gender & & 0.65 & 0.74 & 0.45 & 0.87 & 0.67 & 0.19 & 0.55 \\
\hline Breed x Gender & & 0.42 & 0.93 & 0.87 & 0.09 & 0.13 & 0.36 & 0.22 \\
\hline
\end{tabular}

SEM: Standard error of mean, RBC: red blood cell, HGB: hemoglobin, HCT: hematocrit, MCV: mean corpuscular volume, MCH: mean corpuscular hemoglobin, MCHC: mean corpuscular hemoglobin concentration, RDW: red cell dispersion width.

Table 2. Comparisons of white blood cells and platelets between breeds and genders in 3-year-old Arabian and Thoroughbred horses racing in Turkey

\begin{tabular}{|c|c|c|c|c|c|c|c|c|c|}
\hline & $\mathrm{n}$ & $\begin{array}{c}\text { WBC } \\
(\mathrm{x} 103 / \mu \mathrm{L})\end{array}$ & $\begin{array}{c}\text { NEU } \\
(x 103 / \mu \mathrm{L})\end{array}$ & $\begin{array}{c}\text { LYM } \\
(\mathrm{x} 103 / \mu \mathrm{L})\end{array}$ & NEU/LYM & $\begin{array}{c}\text { MONO } \\
(\mathrm{x} 103 / \mu \mathrm{L})\end{array}$ & $\begin{array}{c}\text { EOS } \\
(\mathrm{x} 103 / \mu \mathrm{L})\end{array}$ & $\begin{array}{c}\text { BASO } \\
(\mathrm{x} 103 / \mu \mathrm{L})\end{array}$ & $\begin{array}{c}\text { PLT } \\
(\mathrm{x} 103 / \mu \mathrm{L})\end{array}$ \\
\hline \multicolumn{10}{|l|}{ Breed } \\
\hline Arabian & 40 & $8.2 \pm 0.2$ & $4.6 \pm 0.2$ & $3.1 \pm 0.1$ & $1.7 \pm 0.2$ & $0.40 \pm 0.03$ & $0.12 \pm 0.02$ & $0.03 \pm 0.01$ & $162.0 \pm 6.0$ \\
\hline Thoroughbred & 40 & $8.5 \pm 0.2$ & $5.0 \pm 0.2$ & $2.9 \pm 0.1$ & $1.8 \pm 0.2$ & $0.39 \pm 0.03$ & $0.13 \pm 0.02$ & $0.04 \pm 0.01$ & $156.0 \pm 6.0$ \\
\hline \multicolumn{10}{|l|}{ Gender } \\
\hline Stallion & 40 & $8.2 \pm 0.2$ & $4.8 \pm 0.2$ & $3.1 \pm 0.1$ & $1.7 \pm 0.2$ & $0.42 \pm 0.03$ & $0.10 \pm 0.02$ & $0.02 \pm 0.01$ & $165.0 \pm 6.0$ \\
\hline Mare & 40 & $8.4 \pm 0.2$ & $4.8 \pm 0.2$ & $2.9 \pm 0.1$ & $1.8 \pm 0.2$ & $0.37 \pm 0.03$ & $0.14 \pm 0.02$ & $0.04 \pm 0.01$ & $153.0 \pm 6.0$ \\
\hline \multicolumn{10}{|l|}{ Breed x Gender } \\
\hline Arabian - Stallion & 20 & $8.3 \pm 0.3$ & $4.7 \pm 0.3$ & $3.2 \pm 0.2$ & $1.7 \pm 0.2$ & $0.40 \pm 0.04$ & $0.10 \pm 0.02$ & $0.02 \pm 0.01$ & $167.0 \pm 8.0$ \\
\hline Arabian - Mare & 20 & $8.1 \pm 0.3$ & $4.5 \pm 0.3$ & $3.0 \pm 0.2$ & $1.8 \pm 0.2$ & $0.41 \pm 0.04$ & $0.14 \pm 0.02$ & $0.03 \pm 0.01$ & $156.0 \pm 8.0$ \\
\hline Thoroughbred-Stallion & 20 & $8.5 \pm 0.3$ & $4.9 \pm 0.3$ & $3.1 \pm 0.2$ & $1.7 \pm 0.2$ & $0.45 \pm 0.04$ & $0.11 \pm 0.02$ & $0.03 \pm 0.01$ & $162.0 \pm 8.0$ \\
\hline Thoroughbred -Mare & 20 & $8.4 \pm 0.3$ & $5.1 \pm 0.3$ & $2.8 \pm 0.2$ & $1.9 \pm 0.2$ & $0.33 \pm 0.04$ & $0.14 \pm 0.02$ & $0.06 \pm 0.01$ & $150.0 \pm 8.0$ \\
\hline SEM & & 0.1 & 0.1 & 0.1 & 0.1 & 0.02 & 0.01 & 0.01 & 4.0 \\
\hline \multicolumn{10}{|l|}{ P-value } \\
\hline Breed & & 0.34 & 0.17 & 0.40 & 0.76 & 0.78 & 0.73 & 0.30 & 0.51 \\
\hline Gender & & 0.46 & 0.92 & 0.17 & 0.58 & 0.19 & 0.14 & 0.11 & 0.16 \\
\hline Breed x Gender & & 0.76 & 0.55 & 0.92 & 0.98 & 0.14 & 0.87 & 0.50 & 0.95 \\
\hline
\end{tabular}

SEM: Standard error of mean, WBC: white blood cell, NEU: neutrophil, LYM: lymphocyte, MONO: monocyte, EOS: eosinophil, BASO: basophil, PLT: platelet. 


\begin{tabular}{|c|c|c|c|}
\hline \multicolumn{4}{|c|}{$\begin{array}{l}\text { Table 3. Normal range of hematological values for 3-year-old Arabian and } \\
\text { Thoroughbred horses racing in Turkey and normal range values of hot-blooded horses. }\end{array}$} \\
\hline Parameters & $\begin{array}{l}\text { Normal range values of Arabian } \\
\text { (\%95 Confidence interval) }\end{array}$ & $\begin{array}{l}\text { Normal range values of Thoroughbred } \\
\text { (\%95 Confidence interval) }\end{array}$ & $\begin{array}{l}\text { Normal Range values of hot-blooded horse } \\
\text { (Adapted from Jain } 1986 \text { and Grondin and Dewitt 2010) }\end{array}$ \\
\hline $\mathrm{RBC}(\mathrm{x} 106 / \mu \mathrm{L})$ & $9.1-9.7$ & $10.4-10.9$ & $6.8-12.9$ \\
\hline $\mathrm{HGB}(\mathrm{g} / \mathrm{dl})$ & $13.9-14.7$ & $15.7-16.5$ & $11.0-19.0$ \\
\hline НСТ (\%) & $40.5-42.5$ & $45.7-47.7$ & $32.0-53.0$ \\
\hline $\operatorname{MCV}(\mathrm{fL})$ & $43.6-45.2$ & $43.2-44.9$ & $37.0-59.0$ \\
\hline MCH (pg) & $15.0-15.5$ & $14.9-15.4$ & $12.0-20.0$ \\
\hline $\mathrm{MCHC}(\mathrm{g} / \mathrm{dL})$ & $34.2-34.7$ & $34.3-34.7$ & $31.0-39.0$ \\
\hline RDW (\%) & $25.7-26.8$ & $26.1-27.2$ & $24.0-27.0$ \\
\hline $\mathrm{WBC}(\mathrm{x} 103 / \mu \mathrm{L})$ & $7.8-8.6$ & $8.1-8.8$ & $5.4-14.3$ \\
\hline $\operatorname{NEU}(x 103 / \mu \mathrm{L})$ & $4.2-5.0$ & $4.6-5.4$ & $2.26-9.58$ \\
\hline LYM ( x103 / $\mu \mathrm{L})$ & $2.9-3.3$ & $2.7-3.2$ & $1.5-7.7$ \\
\hline MONO $(\mathrm{x} 103 / \mu \mathrm{L})$ & $0.35-0.46$ & $0.34-0.45$ & $0.0-1.0$ \\
\hline EOS $(x 103 / \mu \mathrm{L})$ & $0.08-0.15$ & $0.09-0.16$ & $0.0-1.0$ \\
\hline BASO $(x 103 / \mu \mathrm{L})$ & $0.01-0.05$ & $0.02-0.06$ & $0.0-0.29$ \\
\hline PLT $(x 103 / \mu \mathrm{L})$ & $150-173$ & $144-168$ & $100-350$ \\
\hline
\end{tabular}

RBC: red blood cell, HGB: hemoglobin, HCT: hematocrit, MCV: mean corpuscular volume, MCH: mean corpuscular hemoglobin, MCHC: mean corpuscular hemoglobin concentration, RDW: red cell dispersion width, WBC: white blood cell, NEU: neutrophil, LYM: lymphocyte, MONO: monocyte, EOS: eosinophil, BASO: basophil, PLT: platelet.

\section{Results}

All results are shown as means \pm standard error of mean (SEM) in Table-1-2. There were no significant differences between genders in any hematological parameters $(\mathrm{P}>0.05)$. There was also no significant gender $\mathrm{x}$ breed interaction for any investigated parameters $(\mathrm{P}>0.05)$.

The absence of these interaction indicated that the effect of gender on hematological parameters were similar in both breeds. RBC $(\mathrm{P}<0.001)$, HGB $(\mathrm{P}<0.001)$ and HCT $(\mathrm{P}<0.001)$ values were significantly higher in Thoroughbred than Arabian horses but there were no significant differences in other parameters between breeds $(\mathrm{P}>0.05)$. Since neither gender nor gender $\mathrm{x}$ interaction was significant, normal range values for each parameter were shown only for breeds (Table 3 ).

\section{Discussion}

Within the 3-year-old age category of horses running in flat racing in Turkey, Thoroughbreds have been found to have higher RBC, HGB and HCT counts than Arabian horses. No significant differences in erythrocyte indices (MCV, MCH, MCHC, and RDW), total white blood cell and platelet counts, differential white blood cell counts (NEU, LYM, MONO, EOS, BASO) were observed between breeds. Gender related differences were not observed overall as well as in both Thoroughbred and Arabian horses. It has been reported that there are breed differences with hematology of horses (Satue et al 2012). Correct interpretation of equine hematology depends upon whether the individual animal is considered to be one of the so-called "hot-blooded" or "cold-blooded" breeds (Lording 2008). Hot-blooded horses are of Arabian ancestry and include Arabians, Thoroughbreds, Standardbreds, and Quarter horses while the cold-blooded breeds include draft horses, ponies, and hacks (Lording 2008; Padalino et al 2016). In this study, both breeds were hot-blooded and their hematological values were within the normal range for hot-blooded horses (Table 3) but were greater than the values stated for cold-blood horses (Kramer 2000). It has been reported that hot-blooded horses have higher RBC and HGB values than cold-blooded horses resulting in an increase in their oxygen carrying capacity, hence in their athletic performance (Hawkey 2017).

Hematological reference ranges within hot-blooded horses also differ (Steel and Whitlock, 1960). Standardbred horses have lower RBC, HGB, and HCT than Thoroughbred racehorses (McGowan and Hodgson 2014).

This study is noteworthy in that both Arabian and Thoroughbreds were of the same age and were actively racing at the same racecourse. RBC, HGB, and HCT values were higher in Thoroughbreds than Arabians. It has been reported that Thoroughbred had the greatest RBC, HGB, and HCT among hot-blooded horses including Thoroughbreds, Quarter Horses, Appaloosas, Arabians, and Standardbreds (Jain 1986).

Higher RBC, HGB, and HCT values are associated with higher speed and performance (Aslan 2017). It is well known that 
Thoroughbreds run faster and are categorized as speed runners while Arabians are slower in speed and better in endurance, i.e. in long distance (Prince et al 2002).

Although the ratios of concentrates (60\%) and forage (40\%) in the diet were same for both breeds, the concentrates of Arabian diet consisted of mainly crushed barley while those of Thoroughbred diet consisted of crushed oat. According to personal communications with trainers, this nutritional regime is common in Turkey and applied to the most of the racehorses in Turkey. This might also affect the differences in RBC, HGB and HCT values between breeds. Further nutritional researches might be carried out to investigate the effect of two cereals on hematological values in racehorses.

Previous studies have focused on individual hematological parameters of either Arabians (Altınsaat 2008; Rocky et al 2012; Meliani et al 2014; Khasanovich and Vladimirovna 2016) or Thoroughbreds (Piccione et al 2005; Lacerda et al 2006; Uluisik et al 2013) with different ages and training status. RBC, HGB, and HCT values for Arabians in the current study seemed to be higher than previous reports (Jain 1986; Altınsaat 2008). The study by Altınsaat has been performed on foals, yearlings, and adult Arabian horses (age 8-15 years) in stud farms of Turkey whereas the current study was performed on 3-year-old Arabian horses running in flat races. Rocky et al (2012) has reported that age has a major role on hematologic parameters of Arabian horses. Normal adult hematologic values are attained at 2 years of age and then there is a trend towards decline in geriatric horses (McFarlane et al 1998; Satue et al 2014). Moreover, training might be the cause of higher RBC, HCT, HGB in the current study since it has been reported that training result in increases in RBC, HGB, and HCT. Arabian horse racing in Turkey is very popular and these horses are raced more often (2-3 times per month) compared to the other countries where equine industry is much more developed. More racing frequency might be the cause of higher RBC, HGB and HCT.

It seems that RBC, HGB, and HCT values for Thoroughbreds in the current study were higher than previous reports by Jain (1986) but similar to data reported by Sykes (1966). The later study has been performed in 3-year-old and in training Thoroughbreds which is more similar to our study.

There were no significant differences in MCV, MCH, MCHC, and RDW counts between Arabians and Thoroughbreds in the current study. Thoroughbreds have lower MCV value than draft horses but similar value with Quarter Horses (Jain 1986).

There were no significant differences in WBC, differential WBC, and platelet counts between Arabians and Thoroughbreds. WBC count for both breeds in the current study were lower but the neutrophil/lymphocyte ratio was higher compared to previous reports by Jain 1986. Various stress factors and training can increase the neutrophil number in circulation, hence increasing the neutrophil/lymphocyte ratio (Altınsaat 2008; Grondin and
Dewitt 2010).

No significant differences in any parameters between stallions and mares were found for both breeds. It has been reported that minor differences were observed in hematological parameters between males and females (Grondin and Dewitt 2010), however, they were not seen in this study. Hematological differences regarding with gender seem to have limited importance and effect in horses (Satue 2012).

\section{Conclusion}

In conclusion, breed differences, but not gender-related differences, were observed in 3-year-old race horses. It seems there are some differences in some hematological parameters of both Arabians and Thoroughbreds compared to their counterparts in other countries. This might be age-related, related to geographical location, or training status, however, it is advisable for clinicians and researchers to determine their own reference ranges for breeds in their country. Since this study is carried out in only 3-year-old horses, further studies should be carried out in race horses in Turkey to include all ages to provide additional reference ranges for other age horses.

\section{Acknowledgements}

This study was supported by Turkish Jockey Club. I would like to give my special thanks to Prof. Dr. Brian Nielsen from Michigan State University for all his valuable suggestions. I would like to thank also Prof. Dr. Bülent Ekiz from Istanbul University for the assistance in statistical analyses and Dr. Alper Mete from Turkish Jockey Club for the assistance in acquisition of hemogram reports.

\section{References}

Altınsaat Ç, 2008. The Effects of age and gender on Blood Parameters in Arabian Horses. Kafkas Üniv Vet Fak Derg, 14, 173-178.

Aslan R, 2017. Egzersiz Fizyolojisi. In: Spor Atları, Ed; Recep Aslan, First Edition, Nobel, Ankara, Turkey, pp;73-83.

Cebulj- Kadunc N, Bozic M, Kosec M and Cestnik V, 2002. The influence of Age and Gender on Hematological Parameters in Lipizzan Horses. J. Vet. Med A, 49, 217-221.

Ekiz B and Kocak 0, 2005. Phenotypic and genetic parameter estimates for racing traits of Arabian horses in Turkey. J Anim Breed Genet, 122, 349-356.

Güzelbekteș H, Ok M, Şen İ, Coşkun A, 2006. Atlarda uzun süreli fiziksel egzersizin hematolojik ve Bazı biyokimyasal parametreler üzerine etkisi. Eurasian J Vet Sci, 22, 1-2, 027-030.

Hawkey CM, 2017. Comparative Mammalian Hematology: Cellular Components and Blood Coagulation of Captive Wild Animals. Kindle Edition, Butterworth-Heinemann, UK.

Hill EW, Gu J, Eivers SS, Fonseca RG, McGivney BA, Govinda- 
rajan P, Orr N, Katz LM, MacHugh DA, 2010. Sequence Polymorphism in MSTN Predicts Sprinting Ability and Racing Stamina in Thoroughbred Horse. Plos One, 5, 1-6.

Gramm M, Marksteiner R, 2010. The Effect of Age on Thoroughbred Racing Performance. J Equine Sci, 21, 73-78.

Grondin TM and Dewitt SF, 2010. Normal hematology of horse and donkey. In: Schalm's Veterinary Hematology. Eds; Weiss DJ and Wardrope KJ, Sixth edition, Blackwell Publishing, Iowa, USA, pp; 820-828.

Jain NC, 1986. Schalm's Veterinary Hematology, Fourth edition, Lea \& Febiger, Philadelphia, USA, pp; 140-177.

Khasanovich KV, Vladimirovna PL, 2016. Hematological parameters of 2 year old purebred Arabian race horses in different periods of horse racing season. European science review, 21-32.

Kramer JW, 2000. Normal hematology of the horse. In: Schalm's veterinary hematology, Eds; Feldman BF, Zinkl JG, Jain NC, Fifth edition, Blackwell Publishing, Ames IA, USA, pp;1069-1074.

Lacerda L, Campos R, Sperb M, Soares E, Barbosa P, Godinho E, Ferreira R, Santos V, Gonzalez FD, 2006. Hematologic and biochemical parameters in three high performance horse breeds from Southern Brazil. Arch Vet Sci, 11, 40-44.

Lording P, 2008. Erythrocytes. Vet Clin Equine, 24, 225-237.

McFarlane D, Sellon DC, Gaffney D, 1998. Hematologic and serum biochemical variables and plasma corticotropin concentration in healthy aged horses. Am J Vet Res, 59, 1247-1251.

McGowan CM, Hodgson DR, 2014. Hematology and Biochemistry, In: The Athletic Horse, Eds; Hodgson DR., McKeeveer KH, McGowan CM, Second edition, Saunders Elsevier, China, pp; 56-68.

Meliani S, Benallau B, Hamdi A, Bouabdelli S, 2014. The Influence of Age on Hematological Parameters in Post-Partum Pure Bred Arabian Mares Raised in Tiaret Algeria. J. Microb Biochem Technol, 7, 8-10.
Morris DD, 1989. Review of anemia in horses. 1. Clinical signs, laboratory finding and diagnosis. Equine Pract, 11, 27-32.

Padalino B, Rubino G, LacinioR, Petazzi F, 2014. Observations on the Hematology of Standardbred Horses in Training and Racing in Southern Italy. J Equine Vet Sci, 34, 308-402.

Padalino B, Rubino G, Lacinio R, Petazzi F, 2016. A new classification to Diagnose Type of Anemia in Standardbred Horses: A retrospective Study. J Equine Vet Sci, 44, 21-25.

Piccione G, Fazio F, Giudice E, Grasso F, Morgante M, 2005. Nycthemeral change of some hematological parameters in horses. J Appl Biomed, 3, 123-128.

Prince A, Geor R, Harris P, Hoekstra K, Gardner S, Hudson C, Pagan J, 2002. Comparison of the metabolic responses of trained Arabians and Thoroughbreds during high-and low-intensity exercise. Equine Vet J, Suppl 34, 95-99.

Reed SM, Bayly VM, Sellon DC, 2009. Equine Internal Medicine. Third edition, Saunders, UK, pp; 1-1488.

Rocky A, Jalali MR, Gooraninejad S, Pourmadhi M, Naghashpour F, 2012. Reference intervals for hematologic parameters of Arabian horses. Vet Clin Pathol, 1, 37.

Satue K, Hernandez A, Munoz A, 2012. Physiological Factors in the interpretation of Equine Hematological Profile, In: Hematology Science and Practice, Ed; Charles H Lawrie, Intech Open Publisher, Rijeka, Croatia, pp; 573-596.

Satue K, Munoz A and Garbon JC, 2014. Interpretation of Alterations in the Horse Erythrogram. Journal of Hematology Research, 1, 1-10.

Sykes PE, 1966. Hematology as an aid in equine track practice. Proc Am Assoc Eq Prac, 12, 159 - 167.

Steel JD, Whitlock LE, 1960. Observations on the hematology of Thoroughbred and Standardbred horses in training and racing. Aust Vet J, 36, 136-142.

Uluisik D, Keskin E, Ozaydın T, 2013. Age and gender related changes in hematological parameters of thoroughbred foals. Biotech Histochem, 88, 345-349. 